\section{El rey está desnudo}

Hace casi dos siglos, en 1837, Hans Christian Andersen publicó una fábula titulada El nuevo traje del emperador. Cuenta la historia que un monarca que se preocupaba mucho por su vestuario un día oyó que un par de artesanos podían fabricarle la tela más suave que pudiera imaginar, pero, además, con la sugestiva propiedad de que era invisible para los tontos o incapaces. Una vez que le anunciaran que estaba terminado (y sin querer admitir que no veía nada), el rey se puso el inexistente atuendo confeccionado con la tela para participar en un desfile y se paseó delante de todos en ropa interior hasta que un chico exclamó: “¡Pero si el rey está desnudo!”.

Hoy la que se muestra al desnudo es la ciencia. Como nunca antes, un microorganismo que mide 800 veces menos que el diámetro de un pelo (una décima de micrón) y desató a fines del año pasado una pandemia que está poniendo en jaque sistemas sanitarios, sociedades y economías en todo el planeta, le arrebató los ropajes a la maquinaria de conocimiento que construyó el mundo tal como lo conocemos y expuso a los ojos de todos esos engranajes que combinan al mismo tiempo certezas e incertidumbre.

Paradójicamente, después de haber promovido entre el público la imagen rectora del médico y la idea de que la ciencia tiene respuesta para todo, este año los periodistas que trabajamos en estos temas nos vimos enfrentados con la tarea de mostrar ante los legos las bambalinas del trabajo científico, los avances y retrocesos, las pruebas y refutaciones, las controversias y el disenso que son el pan nuestro de cada día para especialistas avezados, pero pocas veces habían sido expuestos a quienes no frecuentan los laboratorios, ni participan de congresos dedicados a discutir los avances en medicina.

Así, nos encontramos descartando la conveniencia de usar barbijo y luego respaldando la necesidad imperiosa de no olvidarlo al salir de casa, o asegurando que el virus es demasiado grande para quedar flotando en aerosoles y después advirtiendo que podía mantenerse suspendido en el aire durante una a dos horas, por citar solo dos casos en los que tuvimos que volver sobre nuestros pasos y desmentir lo que algún tiempo antes habíamos asegurado. Por supuesto, así funciona la ciencia, sobre la mejor evidencia disponible, pero muchos no lo sabían... Los "giros copernicanos" antes se daban en el espacio de décadas, y hoy se suceden semana a semana.
Probablemente no haya información más difícil de transmitir que la falta de respuestas o las verdades provisorias. $\mathrm{Si}$ a esto le sumamos las divergencias en los criterios sobre cuáles son las medidas más efectivas para controlar la circulación del virus (restricciones vs. aperturas, testear a sintomáticos vs. asintomáticos, entre otras), los conflictos de interés, la desesperación y la circulación irrestricta de falsas verdades que tomó por asalto las redes sociales en las que un democrático anonimato puso en pie de igualdad a autoridades en sus campos de estudio con charlatanes (iun grupo al que a veces, incluso, se sumaron científicos de renombre!), el desafío es mayúsculo.

Alguien dijo que la batalla de la pandemia se ganaba en el laboratorio. Me permito disentir: la pandemia no es un hecho meramente biológico, sino también sociológico, cultural, económico. $Y$ en ese escenario, la comunicación y sus portavoces, tanto médicos como periodistas, tenemos un papel protagónico. Ojalá podamos cumplirlo a la altura de lo que exige el momento.

\section{Nora Bär}

Editora de Ciencia y Salud, Diario La Nación

Presidenta de la Red Argentina de Periodismo Científico 